\title{
Perceptions of Pre-Service Secondary Science Teachers on Inquiry- Based Science Education: An Analysis of the Demographic Variables
}

\author{
Cristina García-Ruiz ${ }^{1 *}$, Teresa Lupión-Cobos ${ }^{1}$, Ángel Blanco-López ${ }^{1}$ \\ ${ }^{1}$ Department of Science Education, University of Málaga, Málaga, SPAIN \\ * Corresponding author: crisgarcia@uma.es
}

Received: 18 May $2021 \bullet$ Accepted: 28 Jul. 2021

Citation: García-Ruiz, C., Lupión-Cobos, T., \& Blanco-López, Á. (2021). Perceptions of Pre-Service Secondary Science Teachers on Inquiry-Based Science Education: An Analysis of the Demographic Variables. European Journal of Science and Mathematics Education, 9(4), 168-182. https://doi.org/10.30935/scimath/11205

\begin{abstract}
:
Implementing the inquiry approach in the science classroom represents a challenge for pre-service secondary science teachers due to the perceptions they build around inquiry and determine their future teaching practice. In this work, we analyse the perceptions of 46 students of the science specialities of the Master's Degree in Secondary Education Teaching, using the design of a questionnaire adapted from the PRIMAS project. The results obtained show some initial perceptions of the participants with a very homogeneous profile for the variables analysed, finding them favourable to the inquiry as a teaching approach, although showing some concrete difficulties. We also found some statistically significant differences regarding gender and previous academic and teaching experience. However, the prior research background associated with the science and technological degrees completed by the participants seemed not to affect their perception about inquiry. We finally raise some implications of the results obtained and give some orientation that might be useful for the initial training of secondary science teachers.

Keywords: pre-service secondary science teachers, teachers' perceptions, inquiry-based science education, secondary education
\end{abstract}

\section{INTRODUCTION}

In current Science Education, different international educational institutions and initiatives strongly recommend the use of methodologies such as inquiry (Lederman et al., 2013). Inquiry-based science teaching (IBST) encompasses a series of student-centred methodologies, which construct and reconstruct their learning socially through interaction with the environment (Pedaste et al., 2015) and include resolving real and contextualised problems (Heindl, 2018; Jiménez-Tenorio \& Oliva, 2016).

In the literature, we can find numerous works on how inquiry has a positive impact on the cognitive and attitudinal results of students (Boaventura et al., 2020; Marshall \& Alston, 2014), not only at the level of knowledge and reasoning but also in their attitudes towards science (Chen et al., 2014), encouraging attitudes that promote an increase in vocations towards scientific-technological careers (Sjøberg, 2019). Thus, the inquiry becomes an appropriate practice to understand the nature of science, providing a vision of the scientific world to students, involving them in scientific practice, and favouring the transfer of knowledge (Abd-El-Khalick et al., 2004). All this means that, together with the multiple benefits also described for teachers, IBST might be considered a promising approach to bringing science in context to school life (Marshall \& Alston, 2014). 
Despite the consensus regarding the value of inquiry-based teaching, its application in science teaching is still limited (Fitzgerald et al., 2017) due to the difficulties that teachers encounter for their practice (increased workload, students' resistance, increased responsibility, among others) (Romero-Ariza et al., 2020). Also, its reduced implementation is related to a whole series of teachers' perceptions in this regard (Roehrig \& Luft, 2004), such as assuming that IBST complicates classroom management, that it is incompatible with the extension of the curricula or considering that it is only appropriate with highability students (Rodríguez-Arteche \& Martínez-Aznar, 2016b).

The application of the IBST in the classroom continues to be a challenge since it involves a change in the teaching role towards actions that make it a guide and a motivator, researcher, mentor, or collaborator (Crawford, 2014). This change poses a series of dilemmas for teachers, mostly rooted in beliefs and perceptions that, as Binns and Popp (2013) point out, affect their own identity, influencing their pedagogical decisions and strategies, and might be an obstacle to the practice of inquiry. The construction of these beliefs has its origin both in the initial training they receive as future teachers and their professional practice, with a persistence that is difficult to modify and whose influence is directly related to student learning (Lumpe et al., 2012). From this perspective, it is assumed that, as with students, the different starting points of the pre-service secondary science teachers (PSSTs) should be taken into account in initial training programs (Tiberghien et al., 2018) to adjust the aid for these teachers to acquire the confidence, knowledge, and teaching skills necessary to approach inquiry processes with their students.

A wide variety of investigations have addressed the study of the pre-service teachers' perceptions about inquiry in secondary science education to obtain relevant information to support training programs. However, in many of them, it is still pending to analyse the influence that certain variables, such as teaching experience, research experience or gender, among others, may have on forming such perceptions. Thus, this article focuses on analysing the perception of the PSSTs on the inquiry and the possible influence on this perception of particular demographic and profile variables. This latter aspect has been studied to date mainly for in-service teachers (Silm et al., 2015).

\section{LITERATURE REVIEW}

This section presents a state-of-the-art analysis of PSSTs perceptions concerning inquiry and its use in science classes. Being aware of the complexity in defining the concept of perceptions (Mansour, 2015), in this work, we will refer to it to characterise the idiosyncratic unit of thoughts that affect the teaching practice. Thus, we will consider both the knowledge about the inquiry process and beliefs of selfefficacy, referred to as the ability to successfully implement it, causing a positive impact on student performance (McKeown et al., 2015). Therefore, in this study, we will use the term perceptions in a broad sense that includes attitudes, beliefs, views, and conceptions.

Over the last two decades, although many publications have focused on pre-service teachers' perceptions about inquiry, just a few of them are related explicitly to PSSTs. Thus, we could classify the factors analysed in each study into four large dimensions: the understanding of the inquiry approach $(\mathrm{APCH})$, the inquiry teaching-learning process (ITLP), the difficulties of its implementation (DIFF), or other associated aspects, such as the influence of specific inquiry professional development programs (DEVT). As Table 1 shows, the works are equally distributed between qualitative and quantitative studies, mostly with data from various instruments' triangulation (questionnaires, interviews, or productions, among others).

Regarding the concept of inquiry, there is a lack of understanding of the stages of the inquiry process, particularly those dedicated to the design of resolution strategies and analysis of results, showing PSSTs problems when correctly discerning between research and experimental activities (Baykara \& Yakar, 2020; Çalik et al., 2015; Herranen et al., 2019; Rodríguez-Arteche \& Martínez-Aznar, 2016a, 2017). 
Table 1. Summary of revised works (2001-2020) about PSSTs perceptions of inquiry

\begin{tabular}{llccccc}
\hline Authors & Year & Country & $N$ & Instruments & Analysis & Dimensions \\
\hline Suters et al. & 2002 & USA & 8 & I & Qual. & DEVT \\
Lotter & 2004 & USA & 13 & Q, R & Qual. & DIFF \\
Windschitl & 2004 & USA & 14 & JO, I, R & Qual. & ITLP \\
Qabland & 2008 & USA & 12 & Q, JO, I, R & Qual./Quant. & ITLP \\
Abril et al. & 2014 & Spain & 36 & Q & Quant. & APCH/DIFF \\
Elster et al. & 2014 & Germany & 44 & Q, I, JO & Qual./Quant. & DEVT \\
Mong et al. & 2014 & USA & 6 & Q, R & Qual. & DEVT \\
Çalik et al. & 2015 & Turkey & 117 & Q, P & Quant. & APCH \\
Krämer et al. & 2015 & Germany & 32 & Q, P & Quant. & ITLP \\
Rodríguez-Arteche et al. & 2016 & Spain & 17 & P & Qual. & APCH \\
Cian et al. & 2017 & USA & 4 & Q, I & Qual. & ITLP \\
Rodríguez-Arteche et al. & 2017 & Spain & 24 & Q, T & Quant. & APCH \\
Nuangchalerm & 2017 & Thailand & 10 & Q, JO, I & Quant. & ITLP \\
Seroussi et al. & 2017 & Israel & 23 & I & Qual. & DEVT \\
Herranen et al. & 2019 & Norway & 5 & I, P & Qual. & APCH/ITLP \\
Romero-Ariza et al. & 2020 & Spain, UK & 129 & Q, I & Qual./Quant. & APCH/ITLP/DIFF \\
Baykara et al. & 2020 & Taiwan, Turkey & 168 & Q, I & Qual. & APCH
\end{tabular}

$\underline{N}$ : number of participants; Instruments: I: interviews; JO: journal observation; P: productions; Q: questionnaires; R: reflections; T: tasks. Analysis: Qual.: qualitative; Quant.: quantitative. Dimensions: APCH: inquiry approach; DEVT: inquiry professional development programs; DIFF: difficulties of inquiry implementation; ITLP: inquiry teaching-learning process.

Concerning the teaching-learning process, the results on the teaching role during the inquiry stand out, proving that there is both a lack of confidence in the PSSTs teaching skills and in the tools to support the students' research and guide them towards the analysis of the results and conclusions (Cian et al., 2017; Krämer et al., 2015; Nuangchalerm, 2017; Qablan, 2008; Windschitl, 2004).

One of the aspects analysed is the struggles that the PSSTs associate with the use of the inquiry approach, highlighting the factors related to the planning and assessment of inquiry activities, classroom management, or the resources and restrictions of the educational system (Abril et al., 2014; Lotter, 2004; Romero-Ariza et al., 2020). Although there is a consensus about the positive effect on student motivation, these works show how this is not the case on learning outcomes. Besides, despite the theoretical knowledge, the teachers identify it as essential to carry out the transfer to practice, considering the students' interests and prior background, developing strategies that lead to a better understanding on their part.

Several studies also analyse the relationship between teacher professional development programs and their impact on the perceptions of inquiry (Elster et al., 2014; Mong \& Ertmer, 2014; Seroussi et al., 2017; Suters et al., 2002), demonstrating how, in the long term, they contribute to the construction of knowledge of pedagogical content, offering excellent opportunities to observe and understand the learning process of science.

Knowing, therefore, the difficulties that PSSTs presents when implementing active learning methodologies such as inquiry, as well as the antecedents in the analysis of perceptions about their use, the present study aims to continue studying the perceptions of the PSSTs about the inquiry processes in the context of their initial training, analysing the possible relationships between these perceptions and certain characteristics of these teachers. Since we observe a gap in the literature regarding the study of PSSTs demographic variables that might or not influence their future implementation of the inquiry, we wish to contribute with an in-deep statistically study to this goal. For instance, we find it interesting to analyse the influence of the previous research experience of the PSSTs, which might be a factor particularly favourable since most of them have performed proper research studies in scientific and technological degrees and may gather some confidence when teaching their expertise area (Watters \& Diezmann, 2015). Also, exploring the gender gap, which is still present in scientific and teaching professional careers (Organisation for Economic Co-operation and Development [OECD], 2019), or the 
Table 2. PSSTs participant's profile

\begin{tabular}{lcc}
\hline Gender & $N$ & $\%$ \\
\hline Male & 19 & 41 \\
Female & 27 & 59 \\
& & \\
\hline MEd speciality & $N$ & $\%$ \\
\hline Biology and geology & 31 & 67 \\
Physics and chemistry & 15 & 33
\end{tabular}

\begin{tabular}{lll}
\hline Teaching experience & $N$ & $\%$ \\
\hline University teaching & 13 & 28 \\
Private tutoring & 21 & 46 \\
None & 12 & 26
\end{tabular}

\begin{tabular}{lcc}
\hline Age & $N$ & $\%$ \\
\hline$<25$ & 17 & 37 \\
$25-30$ & 14 & 30 \\
$>30$ & 15 & 33 \\
\hline Degree of access to the MEd & $N$ & $\%$ \\
\hline Biol. & 14 & 30 \\
Biochem, Phar, Chem & 15 & 33 \\
Envir. Sci./Food Sci. & 12 & 26 \\
Phys./Chem. Eng./Forest Eng. & 5 & 11 \\
\hline Research experience & $N$ & $\%$ \\
\hline PhD & 12 & 26 \\
Master's thesis & 11 & 24 \\
Bachelor's thesis & 9 & 20 \\
Other & 5 & 10 \\
None & 9 & 20 \\
\hline
\end{tabular}

N: number of participants; Biol.: Biology; Biochem.: Biochemistry; Phar.: Pharmacy; Chem.: Chemistry; Envir. Sci.: Environmental Science; Food Sci.: Food Science; Phys.: Physics; Chem. Eng.: Chemical Engineering; Forest Eng.: Forest Engineering

age of the participants (Watters \& Diezmann, 2015), since, in recent years, the Spanish Higher Education curriculum has moved towards more innovative and inclusive teaching strategies. By doing so, we expect to create a global vision on this topic and to guide and promote this methodological strategy in the secondary school classroom, identifying fears and difficulties regarding its implementation and assessing the need to create specific inquiry training programs that can contribute to a better transfer into the practice.

\section{RESEARCH QUESTIONS}

Following the stated objectives, we pose the following research questions:

- What are the PSSTs perceptions on the use of the inquiry approach in the classroom?

- What relationships, if any, are found between the perceptions and specific characteristics (gender, age, academic, or research profile, among others) of the PSSTs profiles?

\section{METHOD}

\section{Participants}

We carried out the study on 46 PSSTs of the "Master's Degree in Secondary Education Teaching" (from now on, MEd) from the University of Málaga, belonging to the specialities of "Biology and Geology" (67\%) and "Physics and Chemistry" (33\%), during the 2018/2019 academic year. Most of the participants were women $(59 \%)$, with a majority age range of 25 years or more $(63 \%)$ and also presenting a high research profile $(80 \%)$ as a consequence of carrying out $\mathrm{PhD}$, Master's, or Bachelor's Thesis in careers within the scientific field. More information about the participants is summarised in Table 2.

\section{Research Instrument}

The data were obtained using an adaptation of the questionnaire proposed by the European PRIMAS project (Engeln et al., 2013), dedicated to promoting science teaching and learning by inquiry. For its preparation, starting from the Spanish version (Abril et al., 2014), we reformulated the questions for PSSTs, adapting the verb tenses to reflect the intention concerning their future teaching practice. We also incorporated some questions referring to the possible contribution of the inquiry approach to the development of scientific competencies included in the Spanish science curriculum (Rueda et al., 2017) in order to analyse if the PSSTs perceive how this kind of teaching-learning activities offer opportunities for their development in the students to whom they are directed. The proposed questionnaire 
(Appendix 1), which included a brief description of the IBST, a term unknown to the PSSTs at the beginning of the MEd, follows a four-point Likert-type scale, forcing the participants to define their position clearly: 1 (totally disagree), 2 (disagree), 3 (agree), 4 (totally agree).

The 30 items that compose it, written in a combined positive and negative way, appear structured in three main dimensions. In the first one, aspects of the teaching-learning process of inquiry are raised, such as interaction in the classroom (category 1), experimental activities (category 2), or the importance of inquiry (category 3). The second dimension, divided into several categories, includes questions that focus on knowing the connection between IBST and student motivation (category 4), dependence on initial knowledge (category 5), and contribution to scientific competencies development (category 6). A third dimension focuses on analysing the difficulties associated with the IBST implementation in terms of resources (category 7), classroom management (category 8), and educational system restrictions (category 9), including two open-ended questions aimed at knowing other possible benefits or difficulties besides those inferable mentioned in the Likert-type questions. The responses to these two questions should provide a degree of openness to encourage PSSTs to explore any perspective they felt appropriate about the IBST implementation, in a way to provide some other qualitative evidence.

\section{Data Collection and Analysis}

The questionnaire was implemented at the beginning of the 2018/2019 academic year. In general, in the case of questions worded in the affirmative sense, we have considered those that fall into the category "agree" and "totally agree" as positive answers. On the contrary, for questions written in the negative, we have considered positive those corresponding to the category "disagree" and "totally disagree." To simplify the graphical representation of the results, the mean value was used in the box plots figures, also describing the $25 \%$ and $75 \%$ percentiles.

The validity and reliability of the PRIMAS reference questionnaire (Engeln et al., 2013) derived from the high number of participants (917 in-service teachers, 12 countries), the statistical analysis developed, and the subsequent research it gave rise to (Maaß \& Engeln, 2014). Since the adapted PSSTs questionnaire in its Spanish version has not been validated yet, we performed the analysis item by item, grouping them into categories according to the original PRIMAS questionnaire (Engeln et al., 2013). However, for a more straightforward explanation, we classified the different categories into the three dimensions we already described in the research instrument, but we did not perform a multidimensional analysis, postponing it for later work once the version of the questionnaire has been validated.

To determine the possible significant differences between the profiles of the participants depicted in Table 2 (gender, age, MEd speciality, degrees of access to the MEd, teaching and research experience), data were first coded for input into the RStudio program (version 1.3.1093). Thus, after verifying the non-parametric nature of the data distribution, we performed a statistical study, using the KruskalWallis H-test for multiple independent groups (in our case, age, degree of access, teaching and research experience), and Mann-Whitney U-test for two independent groups (in our case, gender and MEd speciality). For all the factors analysed, a value of the correlation coefficient $p$ lower than 0.05 was established to assume the existence of significant differences.

The analysis of the responses to the open-questions was carried out inductively using coding techniques performed with the Atlas.ti software (version 8.4.4) (www.atlatsti.com) (Saldaña, 2009). The researchers read the answers provided by the PSSTs several times and identified aspects related to the IBST implementation. A total of 12 codes were used, grouped into two main categories (advantages and disadvantages). Finally, the categorization of all the responses was accomplished jointly by the researchers. 
Table 3. Statistically significant differences found per variable and item

\begin{tabular}{|c|c|c|c|c|c|c|}
\hline Variable & Item, $M(S D$ & $p$-val & & & & \\
\hline Gender & Item $3 d$ & 0.03 & & & & \\
\hline Male & $3.32( \pm 0.58)$ & & & & & \\
\hline Female & $3.67( \pm 0.55)$ & & & & & \\
\hline Age & Item $3 d$ & 0.02 & & & & \\
\hline$<25$ & $3.65( \pm 0.49)$ & & & & & \\
\hline $25-30$ & $3.14( \pm 0.66)$ & & & & & \\
\hline$>30$ & $3.71( \pm 0.47)$ & & & & & \\
\hline Degree of Access to MEd & Item $2 \mathrm{~g}$ & 0.04 & & & & \\
\hline Biol. & $3.71( \pm 0.47)$ & & & & & \\
\hline Biochem./Pharm./Chem. & $3.87( \pm 0.35)$ & & & & & \\
\hline Envir. Sci./Food Sci. & $3.33( \pm 0.65)$ & & & & & \\
\hline Phys./Chem. Eng./Forest Eng. & $3.20( \pm 0.84)$ & & & & & \\
\hline Teaching experience & Item $4 \mathrm{c}$ & 0.03 & Item $4 \mathrm{~g}$ & 0.01 & Item $4 \mathrm{n}$ & 0.02 \\
\hline University teaching & $2.23( \pm 0.60)$ & & $2.54( \pm 0.52)$ & & $2.31( \pm 0.75)$ & \\
\hline Private tutoring & $2.86( \pm 0.73)$ & & $3.00( \pm 0.32)$ & & $3.05( \pm 0.59)$ & \\
\hline None & $2.75( \pm 0.45)$ & & $2.50( \pm 0.67)$ & & $2.67( \pm 0.89)$ & \\
\hline
\end{tabular}
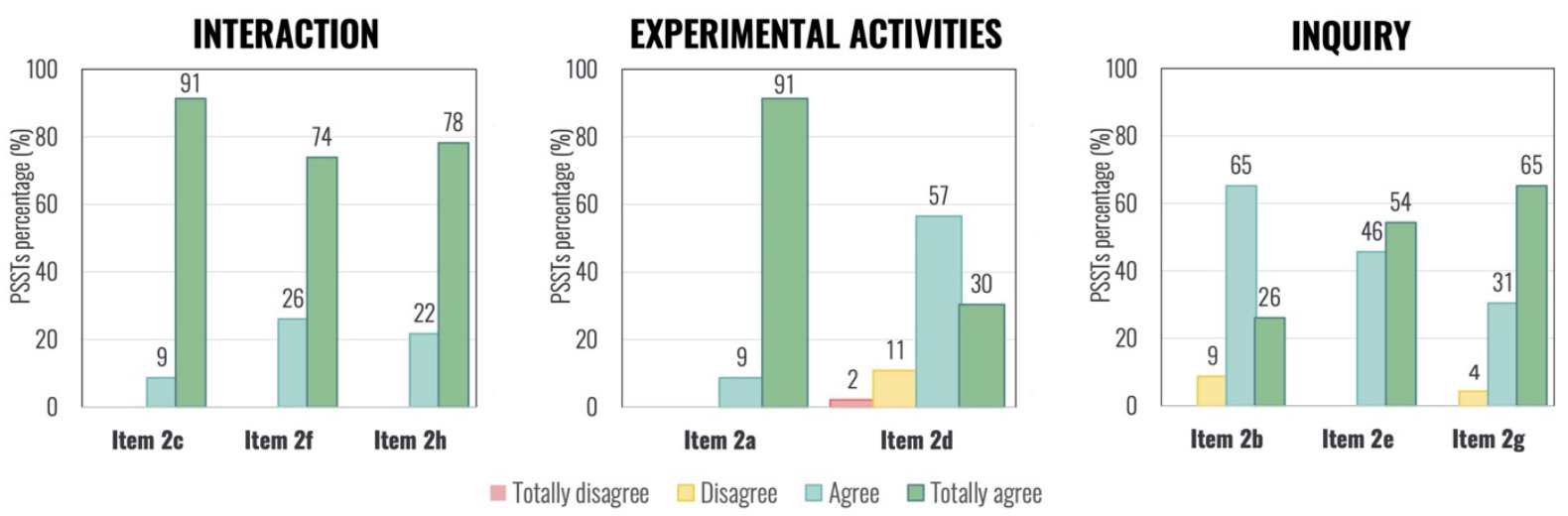

Figure 1. Results on aspects related to the teaching-learning process of inquiry

\section{RESULTS}

Below we present the results organised according to the dimensions and categories specified in the questionnaire description. The complete statistical results containing the means value $(M)$, standard deviation $(S D)$ and $p$-value for each item and PSSTs demographic variable are included in Appendix 2. A brief synthesis of those results involving statistically significant differences is summarised in Table 3 and discussed in subsequent sections.

\section{Results on the Inquiry Teaching-Learning Process}

Figure 1 shows the results regarding aspects analysed in the teaching-learning process of inquiry, related to interaction in the classroom, the relevance given to experimental activities, and the inquiry itself.

In the case of the three items related to interaction in the classroom, we observe a similar pattern, with all the PSSTs agreeing to grant students opportunities to express their ideas (2c), to have and participate in discussions/debates ( $2 \mathrm{f}$ and $2 \mathrm{~h}$ ). All the PSSTs consider experimental activities important (2a), and their perceptions about how they should be developed are closer to the classical approaches on them since the vast majority $(87 \%)$ consider it is essential that students carry out experiments/simulations/modelling following their instructions (2d), which may lead to a distancing from inquiry activities. However, their perceptions about the characteristics of the inquiry are adequate, finding it essential that students design their experiments/investigations (91\%) (2b), that they carry them 
Relation item $2 \mathrm{~g}$ and degree of access

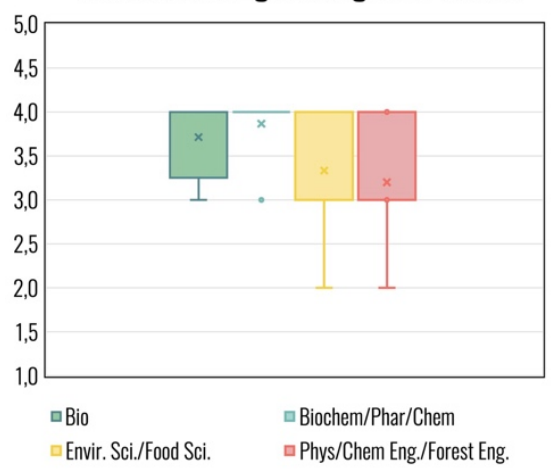

Figure 2. Significant differences regarding the degree of access to the MEd for item $2 \mathrm{~g}$
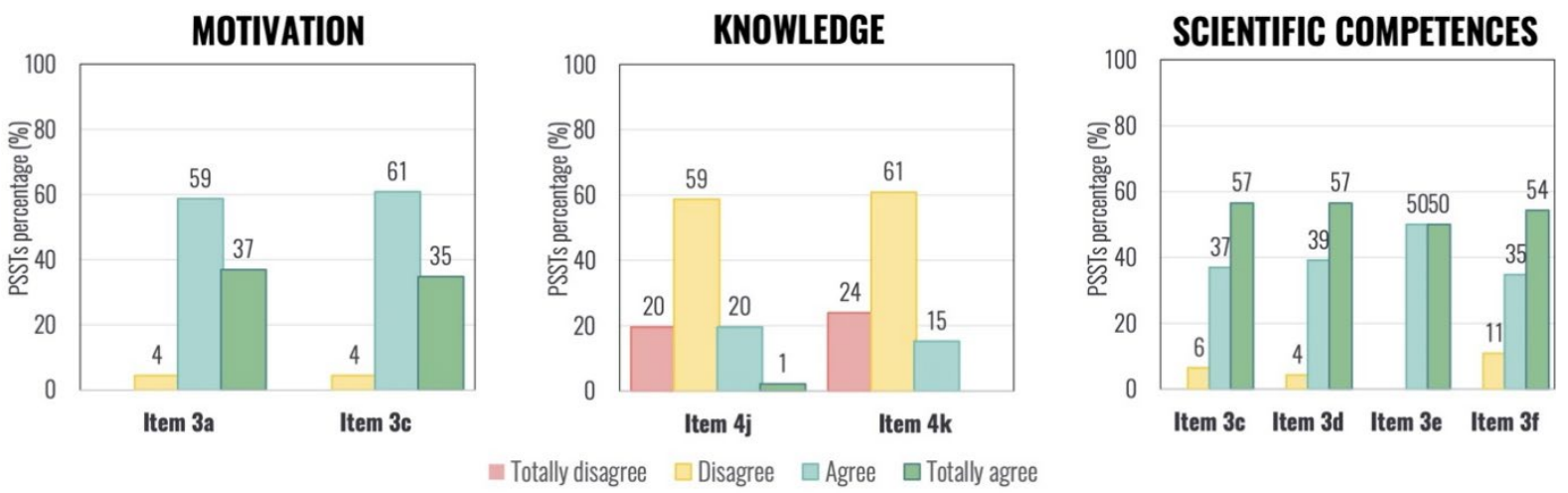

Figure 3. Results on aspects related to the inquiry approach

out to demonstrate/verify their ideas $(100 \%)$ (2e) and that they obtain conclusions from the experiences carried out by themselves (96\%) (2g). In this section, there are only significant differences with respect to the importance of the students obtaining conclusions from the experiments /simulations/models that they carry out $(2 \mathrm{~g})$, related to the degree of access to the MEd $(H=15.75, p=0.04)$. Those PSSTs from degrees in biochemistry, pharmacy, or chemistry, together with those who studied biology, presented mean values higher $(M=3.87, S D=0.35$ and $M=3.71, S D=0.47$, respectively) than those from degrees in environmental sciences or food technology and physics or engineering, which obtained lower mean scores $(M=3.33, S D=0.65$ and $M=3.20, S D=0.84$, respectively) (Figure 2).

\section{Results on the Inquiry Approach}

Figure 3 shows the results of the PSSTs perceptions on the inquiry approach, such as the dependence on ideal knowledge or its contribution to motivation and learning and the development of scientific competencies.

The vast majority of PSSTs (96\%) consider the use of inquiry to be appropriate to address motivation problems in students (3a) and to address learning problems (3b). In the items related to knowledge dependence, we observed that the majority of PSSTs (79\%) do not consider that the practice of inquiry requires extensive initial knowledge on the part of the students $(4 \mathrm{j})$, and a similar percentage (85\%), that can be effective in students with low academic performance (4k).

Regarding the questions corresponding to the development of scientific competencies, practically all of the PSSTs agrees with the contribution of the inquiry to the development of critical thinking in students (94\%) (3c), the acquisition of attitudes and scientific values, and towards science (96\%) (3d), to promote autonomy and personal initiative (100\%) (3e) and to make the role of science in society visible $(89 \%)$ (3f). 


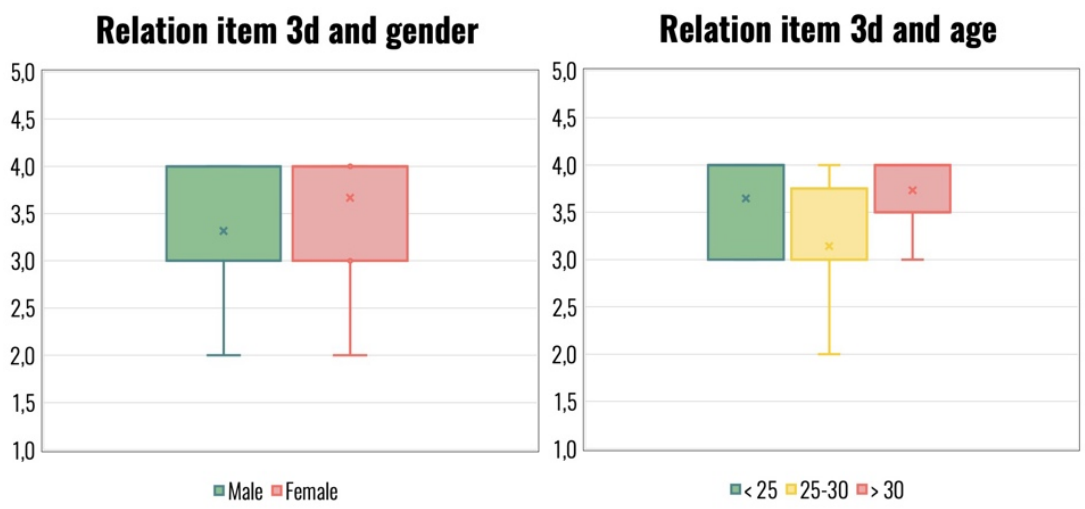

Figure 4. Significant differences regarding gender and age for item $3 \mathrm{~d}$
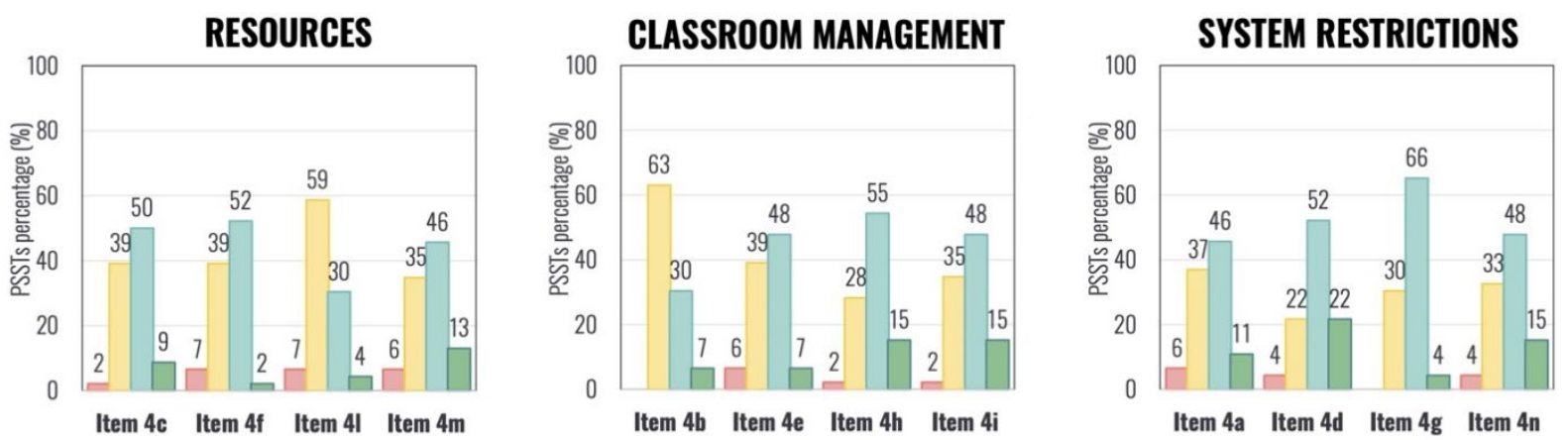

Figure 5. Results on the difficulties associated with the inquiry

In this section, we find significant differences for item $3 \mathrm{~d}$, concerning gender $(U=172.50, p=0.03)$ (with women valuing this relationship higher, $M=3.67, S D=0.55)$ and age $(H=7.71, p=0.02)$ (with the PSSTs in the age range between 25 and 30 years, valuing this relationship lower, $M=3.14, S D=0.66$ ) (Figure 4). This result could be explained by the different distribution of men and women in the three age ranges considered: under 25 (9 women/8 men), between 25 and 30 (7 women/7 men), and over 30 (11 women/4 men).

\section{Results on the Difficulties Associated with the Inquiry Approach}

The results on the difficulties associated with the use of the inquiry, considering the resources, the classroom management, or the system restrictions, are presented in Figure 5.

In the section on resources, the PSSTs perceptions are widely divided into three of the four items that comprise it. More than half (59\%) consider that they would have difficulties in carrying out research activities due to the absence of adequate teaching materials (4c) and due to the lack of sufficient resources such as computers or a laboratory $(4 \mathrm{~m})$. They are also divided in their opinion on the difficulty $(54 \%)$ or not $(46 \%)$ of putting the inquiry into practice because it is not included in the textbooks (4f). There is somewhat more agreement $(66 \%)$ on the need for access to specific training programs (4l).

The results related to classroom climate management show that just over half of the PSSTs (55\%) state that they would not feel safe with this methodology (4e). Thus, the majority $(63 \%)$ consider that carrying out inquiry activities does not have a negative impact on students' behaviour (4b), although they are concerned $(70 \%)$ that students may feel lost and frustrated in their learning $(4 \mathrm{~h})$ and consider $(63 \%)$ that it is difficult to manage group work (4i).

Regarding the restrictions linked to the education system, the majority of the PSSTs (63\%) consider that they would have difficulties in practising the inquiry due to the high number of students per class $(4 n)$, 


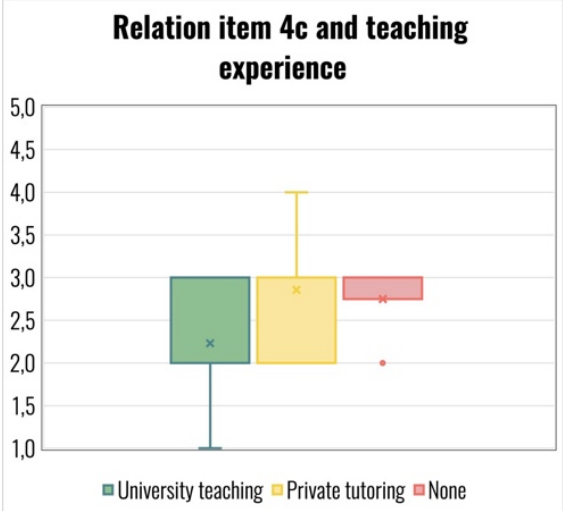

Figure 6. Significant differences regarding teaching experience and item $4 \mathrm{c}$
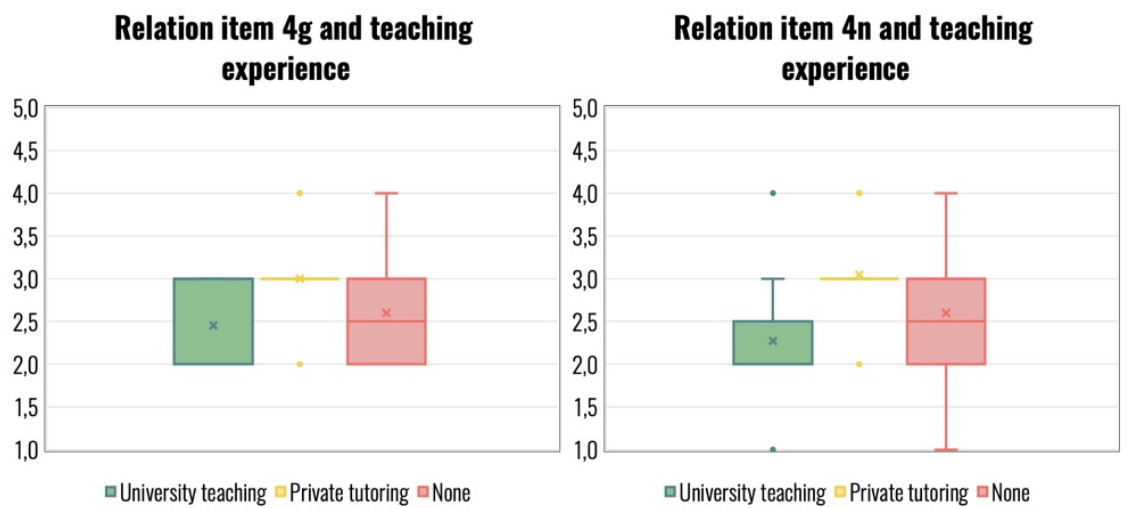

Figure 7. Significant differences regarding teaching experience and items $4 \mathrm{~g}$ and $4 \mathrm{n}$

or that the evaluations the students face do not contemplate the inquiry $(70 \%)(4 \mathrm{~g})$. Slightly higher is the percentage $(74 \%)$ that perceives the lack of time to complete the schedule as a difficulty (4d). On the contrary, the results are more balanced with respect to the perception as difficulty (57\%) or not (43\%) because the curriculum does not promote IBST (4a).

Within the difficulties associated with the use of resources, we found a significant difference $(H=6.84$, $p=0.03$ ) for item $4 \mathrm{c}$, in which the lack of adequate didactic materials is stated as a difficulty when implementing inquiry-based teaching (Figure 6). The result obtained is related to the previous teaching experience of the participants; PSSTs who had taught higher education prior to the MEd showed lower means $(M=2.23, S D=0.60)$ than those who had taught private or tutoring classes in previous stages $(M$ $=2.86, S D=0.73)$. The latter, in turn, obtained a similar score to those who had no previous teaching experience $(M=2.75, S D=0.45)$.

On the other hand, significant differences are also observed in items $4 \mathrm{~g}(H=10.17, p=0.01)$ and $4 \mathrm{n}(H=$ $8.23, p=0.02$ ), both dependent on teaching experience (Figure 7). In the case of those PSSTs who had carried out some previous teaching practice (university or private classes), the difficulty associated with the fact that the evaluations did not include inquiry activities was scored higher $(M=2.54, S D=0.52$ and $M=3.00, S D=0.32$, respectively). The results are different when asked about the number of students and the effectiveness of the inquiry, being the PSSTs who taught university teaching those who perceive it as a lower difficulty $(M=2.31, S D=0.75)$.

This dimension also includes two open-ended questions aimed at finding out other possible benefits (3g) or difficulties (4o) associated with the implementation of the inquiry in the secondary school classroom, and the results of which are shown in Figure 8.

In general, only $22 \%$ of the PSSTs were able to propose additional benefits to those exposed throughout the questionnaire items, highlighting the promotion of cooperation in students $(7 \%)$ or improvement in 


\section{ADDITIONAL BENEFITS}

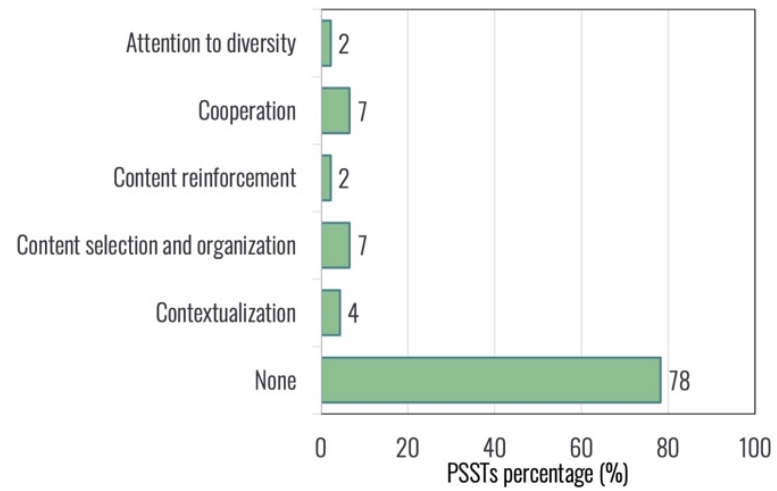

ADDITIONAL DIFFICULTIES

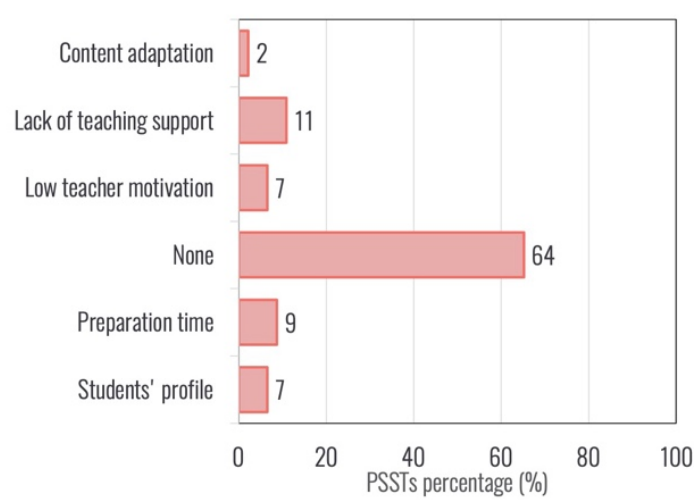

Figure 8. Additional benefits and difficulties found by the PSSTs

searching and selecting information (7\%). At the same time, only $36 \%$ highlight additional difficulties, among which it is worth mentioning the lack of teaching support (11\%) or the longer preparation time $(9 \%)$.

\section{DISCUSSION AND CONCLUSIONS}

We will approach the discussion of the results and the conclusions organized around our research questions. Hence, for the first one, we will consider the full quantitative results obtained in the Likerttype questionnaire in terms of PSSTs percentage. For doing so, we will also examine the responses given to the open-ended questions. On the other hand, for the second question, we will refer to the statistical tests developed to determine whether there was any meaningful difference among the demographic variables studied.

For the first research question (what are the PSSTs perceptions on the use of the inquiry approach in the classroom?), the results show, in general terms, an initial PSSTs perception, considered it as the idiosyncratic unit of thoughts that affect the teaching practice (Mansour, 2015), favourable to the inquiry as a teaching approach. We find the results referring to the teaching-learning process highly satisfactory, with a high percentage of PSSTs considering this type of methodologies appropriate to promote student motivation and improve learning problems, in line with the educational implications described in the literature (Aguilera et al., 2018; Lotter, 2004). The fact that practically all PSSTs consider that the efficiency and success when applying this approach are independent of the level of prior knowledge of the students or academic performance encourages us to think that it can be implemented in different educational contexts, thus confirming the results obtained by relevant research in this regard (Vidal et al., 2017).

It is important to note that the vast majority of PSSTs coincide in stating that inquiry helps strengthen key aspects of scientific competencies, such as the promotion of scientific literacy, the development of critical thinking or autonomy, and making the social role of science more visible and closer. These results are in accordance with those described in the literature (Franco-Mariscal, 2015; Rueda et al., 2017).

Equally encouraging are the results obtained about the importance of giving students opportunities to express their ideas, the foundation pillar of correct implementation, with all PSSTs recognising this process as fundamental. Also, adequate perceptions about essential characteristics of the inquiry processes, although, in parallel, the vast majority of PSSTs position themselves in favour of carrying out experimental activities following the teacher's instructions, considering it essential that they design their experiments/investigations. These results make us consider that, for these participants, there is a preconception linked to the dichotomy of experimental/inquiry activities, linked to more traditional teaching models (Rodríguez-Arteche \& Martínez-Aznar, 2016a). With relative frequency, the teaching 
of experimental activities is carried out in the form of a "recipe", with the teachers providing precise and structured instructions to their students. Sometimes the teachers mistakenly identify this procedure as an inquiry activity (Pérez \& Furman, 2016), although it does not include the formulation of questions, the planning of the experimental design, or the discussion of the results, key aspects in scientific practice.

This dichotomy may be motivated, not so much by the different perceptions between both types of activities, but by the concern that PSSTs manifest about the order and control of the class (Windschitl, 2003) associated with the high number of students per class, they may be involved in more open activities such as the inquiry. In any case, these previous ideas are directly related to the instructional model that they later exercise in the classroom (Lotter et al., 2006), so it is crucial to influence training programs in these aspects, making PSSTs aware that autonomous work and open activities have to mean a loss of control of the class by the teacher. This idea may also be behind the fact that close to half of the PSSTs consider that applying inquiry activities can negatively influence their students' behaviour (and may be associated with problems working in collaborative groups). This may be contributed by the fact that about $60 \%$ show high insecurity when implementing it and also demand specific training programs and courses, a result in accordance with those described in the literature (Krämer et al., 2015; Qablan, 2008).

Regarding the second research question, (what relationships, if any, are found between the perceptions and specific characteristics (gender, age, academic, or research profile, among others) of the PSSTs profiles?) the results obtained show a homogeneous profile of the participating PSSTs around the variables studied, finding only significant differences for some of the variable (s) in 5 of the questionnaire's 30 items.

One of the most striking is the gender difference in investigating and promoting scientific attitudes and values and towards science, a relationship best valued by the female gender. This result could be consistent with that of Minor et al. (2002), in which female teachers valued enthusiasm for teaching more than their peers. For this same relationship, we observe differences in terms of age groups, which could also be explained by the different distribution of men and women in the three age ranges.

Another difference appears with the academic profile. Here, we perceive a bias in students' importance obtaining conclusions derived from their experiments, simulations, or modelling. PSSTs who completed degrees such as chemistry or biology were clearly in agreement compared to physics or chemical engineering. It should be noted that this result has not been discussed so far in PSSTs literature. It is not easy to explain this difference, considering that all these science degrees include many credits for practical activities. Although the more or less open nature of these activities during their degree training could influence their perception of obtaining conclusions, the relationship between these aspects should be studied in depth in future studies.

The previous teaching profile of the PSSTs has also been analysed, and we find several differences. On the one hand, those PSSTs who had already taught at higher education found the lack of teaching materials or the high number of students per class less relevant when applying inquiry activities. These results were totally opposite to those without previous teaching experience or with some experience at the level of tutoring classes, who are overwhelmed by the high volume of students or the lack of resources, identifying greater difficulties in implementing the inquiry approach. To the best of our knowledge, these results represent some novelty in the study of the PSSTs perceptions, with no other study in the literature statistically analysing the influence of previous teaching profile.

Finally, in a study that deals with inquiry perceptions, it is striking that no significant differences were found regarding the research profile. With a sample in which about $80 \%$ of the PSSTs have carried out some research activity (PhD, MSci or BSci), no differences are found compared to the $20 \%$ of participants who have not had previous contact with scientific investigation. This result shows that it is not enough to get involved in an activity such as research to modify the earlier ideas about the scientific practice, but that there is a need to accompany the research activity with the reflection of the process itself 
(Rönnebeck et al., 2016). Consequently, we consider that this aspect should be the object of further investigation, to deep into why students who have already experienced scientific research (academic or professional) manifest such perceptions.

\section{Limitation of the Study}

The results and conclusions raised by this study have been obtained with a reduced number of PSSTs, which leads us to consider that we cannot establish generalisable findings extrapolated to other contexts. Hence, we understand this research as an exploratory study on the influence of some demographic variables affecting the PSSTs perceptions on inquiry. However, we are aware that some longitudinal research focusing on the previous PSSTs background, together with the quantitative analysis we provide, may offer a deeper understanding, and we consider it for future work.

Despite that the original PRIMAS questionnaire was validated across different countries, we understand that the Spanish version we adapted needs to undertake validation. By doing so, we hope we would be able to perform some further analysis regarding the relationships among the different dimensions and categories we already established.

\section{Educational Implications}

Although the results obtained satisfactorily show a predisposition of PSSTs towards the use of inquiry in their future teaching practice, some difficulties appear that could be solved during the initial training programme, MEd. Other difficulties related to contextual aspects of educational practice (curricula, materials, resources, and ratio) are out of reach.

We consider it essential to carry out specific interventions that provide the confidence necessary for a correct application of the inquiry activities in the classroom and answer the questions that these PSSTs pose as drawbacks, as well as carry out a follow-up analysis to compare the evolution of perceptions and verify the usefulness of the training programs.

In this sense, promoting training actions that highlight the nature of science and scientific inquiry could result in better development and monitoring of inquiry activities (Mesci et al., 2020). For this reason, we consider interesting the possible self-reflection of the PSSTs on their teaching and research profile at the beginning of their teaching training. Thus, in the first case, it would allow PSSTs to become aware of the limitations derived from previous teaching experience, and in the second one, to describe their own research experience and identify the elements of the inquiry that we want to include in secondary education.

Author contributions: All authors were involved in concept, design, collection of data, interpretation, writing, and critically revising the article. All authors approve final version of the article.

Funding: This study is part of the project PID2019-105765GA-I00 "Citizens with critical thinking: a challenge for teachers in science education", funded by the Spanish National R\&D Plan, through its 2019 research call, and the project B1-2020_23 "Development and monitoring of the teaching identity of Physics and Chemistry pre-service and in-service secondary education teachers through a specific inquiry training program in the MEd", funded by the University of Málaga. Dr GarcíaRuiz thanks the "Plan Propio" of the University of Málaga for the postdoctoral grant received.

Declaration of interest: The authors reported no potential conflicts of interest.

Data availability: Data generated or analysed during this study are available from the authors on request.

\section{REFERENCES}

Abd-El-Khalick, F., Boujaoude, S., Duschl, R., Lederman, N. G., Mamlok-Naaman, R., Hofstein, A., Niaz, M., Treagust, D., \& Tuan, H. L. (2004). Inquiry in science education: international perspectives. Science Education, 88, 397-419. https://doi.org/10.1002/sce.10118

Abril, A. M., Romero, M., Quesada, A., \& García, F. J. (2014). Creencias del profesorado en ejercicio y en formación sobre el aprendizaje por investigación [Inquiry-based learning in secondary school: in-service and pre-service teachers' believes]. Revista Eureka Sobre Enseñanza y Divulgación de las Ciencias, 11, 22-33. https://doi.org/10.25267/Rev_Eureka_ensen_divulg_cienc.2014.v11.i1.04 
Aguilera, D., Martín-Páez, T., Valdivia-Rodríguez, V., Ruiz-Delgado, Á., Williams-Pinto, L., Vílchez-González, J. M., \& PeralesPalacios, F. J. (2018). La enseñanza de las ciencias basada en la indagación. Una revisión sistemática de la producción española [Inquiry-based science education. A systematic review of Spanish production]. Revista de Educacion, 381, 259274. https://doi.org/10.4438/1988-592X-RE-2017-381-388

Baykara, H., \& Yakar, Z. (2020). Pre-service science teachers' views about scientific inquiry: The case of Turkey and Taiwan. Turkish Online Journal of Qualitative Inquiry, 11(2), 161-192. https://oi.org/10.17569/tojqi.618950

Binns, I. C., \& Popp, S. (2013). Learning to teach science through inquiry: experiences of pre-service teachers. Electronic Journal of Science Education, 17, 1-24. http://ejse.southwestern.edu/article/view/11346

Boaventura, D., Faria, C., \& Guilherme, E. (2020). Impact of an inquiry-based science activity about climate change on development of primary students' investigation skills and conceptual knowledge. Interdisciplinary Journal of Environmental and Science Education, 16(4), e2225. https://doi.org/10.29333/ijese/8554

Çalik, M., Ebenezer, J., Özsevgeç, T., Küçük, Z., \& Artun, H. (2015). Improving science student teachers' self-perceptions of fluency with innovative technologies and scientific inquiry abilities. Journal of Science Education and Technology, 24(4), 448-460. https://doi.org/10.1007/s10956-014-9529-1

Chen, H. T., Wang, H. H., Lin, H. S., Lawrenz, F. P., \& Hong, Z. R. (2014). Longitudinal study of an after-school, inquiry-based science intervention on low-achieving children's affective perceptions of learning science. International Journal of Science Education, 36, 2133-2156. https://doi.org/10.1080/09500693.2014.910630

Cian, H., Dsouza, N., Lyons, R., \& Cook, M. (2017). Influences on the development of inquiry-based practices among pre-service teachers. Journal of Science Teacher Education, 28(2), 186-204. https://doi.org/10.1080/1046560X.2016.1277832

Crawford, B. A. (2014). From inquiry to scientific practices in the science classroom. In N. G. Lederman \& S. K. Abell (Eds.), Handbook of Research on Science Education. Routledge. https://doi.org/10.4324/9780203097267

Elster, D., Barendziak, T., Haskamp, F., \& Kastenholz, L. (2014). Raising standards through INQUIRE in pre-service teacher education. Science Education International, 25, 29-39.

Engeln, K., Euler, M., \& Maass, K. (2013). Inquiry-based learning in mathematics and science: A comparative baseline study of teachers' beliefs and practices across 12 European countries. ZDM - International Journal on Mathematics Education, 45(6), 823-836. https://doi.org/10.1007/s11858-013-0507-5

Fitzgerald, M., Danaia, L., \& McKinnon, D. H. (2017). Barriers inhibiting inquiry-based science teaching and potential solutions: perceptions of positively inclined early adopters. Research in Science Education, 49, 543-566. https://doi.org/10.1007/s11165017-9623-5

Franco-Mariscal, A. J. (2015). Competencias científicas en la enseñanza y el aprendizaje por investigación. Un estudio de caso sobre corrosión de metales en secundaria [Scientific competences in teaching and learning through research. A case study about the corrosion of metals in secondary education]. Enseñanza de las Ciencias, 33(2), 231. https://doi.org/10.5565/rev/ensciencias. 1645

Heindl, M. (2018). Inquiry-based learning and its possibilities for primary schools with fewer digital resources - a qualitative study. Pedagogical Research, 3(3), 1-8. https://doi.org/10.20897/pr/3932

Herranen, J., Kousa, P., Fooladi, E., \& Aksela, M. (2019). Inquiry as a context-based practice - a case study of pre-service teachers' beliefs and implementation of inquiry in context-based science teaching. International Journal of Science Education, 41(14), 1977-1998. https://doi.org/10.1080/09500693.2019.1655679

Jiménez-Tenorio, N., \& Oliva, J. M. (2016). Aproximación al estudio de las estrategias didácticas en ciencias experimentales en formación inicial del profesorado de Educación Secundaria: descripción de una experiencia [Approach to the study of didactic strategies in experimental sciences in initial training of secondary school teachers: description of an experience]. Revista Eureka Sobre Enseñanza y Divulgación de las Ciencias, 13, 121-136. http://hdl.handle.net/10498/18018

Krämer, P., Nessler, S. H., \& Schlüter, K. (2015). Teacher students' dilemmas when teaching science through inquiry. Research in Science and Technological Education, 33(3), 325-343. https://doi.org/10.1080/02635143.2015.1047446

Lederman, N. G., Lederman, J. S., \& Antink, A. (2013). Nature of science and scientific inquiry as contexts for the learning of science and achievement of scientific literacy. International Journal of Education in Mathematics, Science and Technology, 1, 138-147. https://doi.org/10.18404/ijemst.19784

Lotter, C. (2004). Pre-service science teachers' concerns through classroom observations and student teaching: special focus on inquiry teaching. Science Educator, 13(1), 29-38.

Lotter, C., Harwood, W. S., \& Bonner, J. J. (2006). Overcoming a learning bottleneck: inquiry professional development for secondary science teachers. Journal of Science Teacher Education, 17, 185-216. https://doi.org/10.1007/s10972-005-9002-3

Lumpe, A., Czerniak, C., Haney, J., \& Beltyukova, S. (2012). Beliefs about teaching science: the relationship between elementary teachers' participation in professional development and student achievement. International Journal of Science Education, 34, 153-166. https://doi.org/10.1080/09500693.2010.551222

Maaß, K., \& Engeln, K. (2014). Report on the large-scale survey about inquiry based learning and teaching in the European partner countries.

Mansour, N. (2015). science teachers' views and stereotypes of religion, scientists and scientific research: a call for scientist-science teacher partnerships to promote inquiry-based learning. International Journal of Science Education, 37(11), 1767-1794. https://doi.org/10.1080/09500693.2015.1049575 
Marshall, J. C., \& Alston, D. M. (2014). Effective, sustained inquiry-based instruction promotes higher science proficiency among all groups: A 5-year analysis. Journal of Science Teacher Education, 25, 807-821. https://doi.org/10.1007/s10972-014-9401-4

McKeown, T. R., Abrams, L. M., Slattum, P. W., \& Kirk, S. V. (2015). Enhancing teacher beliefs through an inquiry-based professional development program. Journal of Education in Science, Environment and Health, 2(1), 85. https://doi.org/10.21891/jeseh.30143

Mesci, G., Schwartz, R. S., \& Pleasants, B. A. S. (2020). Enabling factors of pre-service science teachers' pedagogical content knowledge for nature of science and nature of scientific inquiry. Science and Education, 29, $263-297$. https://doi.org/10.1007/s11191-019-00090-w

Minor, L. C., Onwuegbuzie, A. J., Witcher, A. E., \& James, T. L. (2002). Pre-service teachers' educational beliefs and their perceptions of characteristics of effective teachers. Journal of Educational Research, 96(2), 116-127. https://doi.org/10.1080/00220670209598798

Mong, C. J., \& Ertmer, P. A. (2014). Examining the impact of a professional development course on stem teachers' acceptance of and intent to implement problem-based learning. Dissertation Abstracts International Section A: Humanities and Social Sciences, 74. https://doi.org/10.13140/2.1.1645.7608

Nuangchalerm, P. (2017). Relationship between preferred and actual opinions about inquiry-based instruction classroom. European Journal of Science and Mathematics Education, 5(1), 67-73. https://doi.org/10.30935/scimath/9498

Organisation for Economic Co-operation and Development [OECD]. (2019). TALIS 2018 results (Volume I): teachers and school leaders as lifelong learners. https://doi.org/10.1787/c9813405-ar

Pedaste, M., Mäeots, M., Siiman, L. A., de Jong, T., van Riesen, S. A. N., Kamp, E. T., Manoli, C. C., Zacharia, Z. C., \& Tsourlidaki, E. (2015). Phases of inquiry-based learning: definitions and the inquiry cycle. Educational Research Review, 14, 47-61. https://doi.org/10.1016/j.edurev.2015.02.003

Pérez, M. C. B., \& Furman, M. (2016). What is a scientific experiment? The impact of a professional development course on teachers' ability to design an inquiry-based science curriculum. International Journal of Environmental and Science Education, 11, 1387-1401. https://doi.org/10.12973/ijese.2016.353a

Qablan, A. (2008). Why are we doing this? Preservice science teachers' interpretations of the role of open inquiry in understanding teaching. Journal of Institutional Research, 14(1), 24-42.

Rodríguez-Arteche, I., \& Martínez-Aznar, M. M. (2016a). Indagación y modelos didácticos: La reflexión de cuatro profesores de Física y Química en formación inicial [Inquiry and teaching models: reflection of four preservice Physics and Chemistry teachers]. Campo Abierto. Revista de Educación, 35, 145-160. http://dehesa.unex.es/bitstream/handle/10662/7198/02139529_35_1_145.pdf? sequence=1\&isAllowed=y

Rodríguez-Arteche, I., \& Martínez-Aznar, M. M. (2016b). Introducing inquiry-based methodologies during initial secondary education teacher training using an open-ended problem about chemical change. Journal of Chemical Education, 93, 15281535. https://doi.org/10.1021/acs.jchemed.5b01037

Rodríguez-Arteche, I., \& Martínez-Aznar, M. M. (2017). Contraposición de ideas sobre la indagación entre futuros profesores y estudiantes de secundaria. X Congreso Internacional Sobre Investigación en Didáctica de las Ciencias, 2937-2944.

Roehrig, G. H., \& Luft, J. A. (2004). Constraints experienced by beginning secondary science teachers in implementing scientific inquiry lessons. International Journal of Science Education, 26, 3-24. https://doi.org/10.1080/0950069022000070261

Romero-Ariza, M., Quesada, A., Abril, A. M., Sorensen, P., \& Oliver, M. C. (2020). Highly recommended and poorly used: English and Spanish science teachers' views of Inquiry-based Learning (IBL) and its enactment. Eurasia Journal of Mathematics, Science and Technology Education, 16(1), 1-16. https://doi.org/10.29333/ejmste/109658

Rönnebeck, S., Bernholt, S., \& Ropohl, M. (2016). Searching for a common ground. A literature review of empirical research on scientific inquiry activities. Studies in Science Education, 52(2), 161-197. https://doi.org/10.1080/03057267.2016.1206351

Rueda, J. A., Blanco, Á., España, E., \& Brero, V. B. (2017). Justificaciones de profesorado de ciencias en formación inicial para la selección de actividades educativas. Influencia de una propuesta formativa [Preservice secondary science teachers' justifications to select teaching and learning activities. Influence of a training proposal]. Profesorado, Revista de Currículum y Formación Del Profesorado, 23, 277-300. https://doi.org/10.30827/profesorado.v23i2.9685

Saldaña, J. (2009). The coding manual for qualitative researchers. SAGE.

Seroussi, D.-E., Yaffe, Y., \& Sharon, R. (2017). “Careful, now you are both the learner and the teacher!”: student teachers' evaluation of inquiry-based peer lecturing as a tool in teacher training. International Education Studies, 10(6), 100. https://doi.org/10.5539/ies.v10n6p100

Silm, G., Tittsaar, K., Pedaste, M., Zacharia, Z. C., \& Papaevripidou, M. (2015). Teacher's readiness to use inquiry-based learning: an investigation of teachers' sense of efficacy and attitudes toward inquiry-based learning. Science Education International, 28(4), 315-325.

Sjøberg, S. (2019). Critical Perspectives on Inquiry-Based Science Education (IBSE) in Europe. Position Paper Written for EUN Partnership, European Schoolnet, March. https://www.researchgate.net/publication/331529566_Critical_Perspectives_ on_Inquiry-Based_Science_Education_IBSE_in_Europe 
Suters, L., Melear, C. T., \& Hickok, L. G. (2002). Views of science teachers one-three years after a pre-service inquiry-based research course. Annual International Conference of the Association for the Education of Teachers in Science, 1-9. http://ezproxy.library.usyd.edu.au/login?url=http://search.proquest.com/docview/62287120?accountid=1475

Tiberghien, A., Badreddine, Z., \& Cross, D. (2018). Designing teacher education and professional development activities for science learning. In O. E. Tsivitanidou, P. Gray, E. Rybska, L. Louca, \& C. P. Constantinou (Eds.), Professional Development for Inquiry-Based Science Teaching and Learning (pp. 245-259). Springer. https://doi.org/10.1007/978-3-319-91406-0_13

Vidal, M., Yebra, M., \& Membiela, P. (2017). Trabajando proyectos de indagación científica con estudiantes de bajo rendimiento académico. X Congreso Internacional Sobre Investigación en Didáctica de las Ciencias, 1485-1490.

Watters, J. J., \& Diezmann, C. M. (2015). Challenges confronting career-changing beginning teachers: a qualitative study of professional scientist becoming science teachers. Journal of Science Teacher Education, 26(2), 163-192. https://doi.org/10.1007/s10972-014-9413-0

Windschitl, M. (2003). Inquiry projects in science teacher education: what can investigative experiences reveal about teacher thinking and eventual classroom practice? Science Education, 87(1), 112-143. https://doi.org/10.1002/sce.10044

Windschitl, M. (2004). Folk theories of "inquiry:" How pre-service teachers reproduce the discourse and practices of an atheoretical scientific method. Journal of Research in Science Teaching, 41(5), 481-512. https://doi.org/10.1002/tea.20010 


\section{APPENDIX 1}

\section{IBST Questionnaire}

\section{IDENTIFICATION}

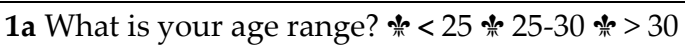

$1 \mathrm{~b}$ Please, indicate your gender.

1c Please, indicate your MEd specialty.

1d From what degree did you access to the MEd?

1e Have you had any previous teaching experience? Could you describe it?

1f Have you had any previous research experience? Could you describe it?

\section{TEACHING-LEARNING PROCESS}

\section{To what extent do you agree with the following statements?}

2a It is important to carry out practical activities.

$2 \mathbf{b}$ It is essential that students design their own experiments/investigations.

2c It is important to provide opportunities for students to express and explain their own ideas.

$2 \mathbf{d}$ It is essential that students perform experiments/simulations/modeling following my instructions.

2e Students should conduct investigations/experiments to test their own ideas.

$2 \mathrm{f}$ I consider it necessary for students to have discussions/debates on the topic we are working on.

$\mathbf{2 g}$ It is essential that students draw conclusions from the experiments/simulations/models that they have carried out.

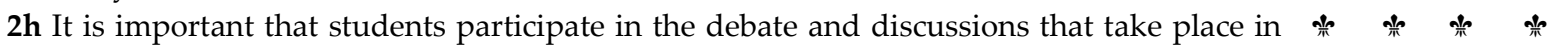
class.

\section{YOUR VISION AS A FUTURE TEACHER}

\begin{tabular}{|c|c|c|c|c|}
\hline 3 I think that IBST... & TD & D & A & TA \\
\hline 3a is well suited to overcome problems with students' motivation. & 桌 & 年 & * & 秊 \\
\hline $3 b$ is well suited to overcome students' learning problems. & s. & 等 & 其 & 敗 \\
\hline $3 c$ develops critical thinking in students. & 桌 & at & 帛 & in \\
\hline 3d favors the acquisition of scientific attitudes and values towards science. & s. & 然 & * & 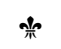 \\
\hline 3e promotes the development of students' autonomy and personal initiative. & 紫 & $\frac{6}{3}$ & 草 & 点 \\
\hline $3 f$ helps to make the role of science visible in society. & in & 年 & 䄅 & 曾 \\
\hline
\end{tabular}
applying inquiry? Justify your answer.

4 I would have difficulties in implementing IBST, because...

4a the curriculum does not encourage IBST.

4b I would worry about students' discipline being more difficult in IBST lessons.

$4 \mathrm{c}$ I would have a lack of adequate teaching materials.

$4 \mathrm{~d}$ there is not enough time in the curriculum.

4e I wouldn't feel confidents with IBST.

4f IBST is not included in textbooks.

$4 \mathrm{~g}$ my students have to take assessments that don't reward IBST

4h I would worry about my students getting lost and frustrated in their learning.

$4 \mathbf{i}$ group work is difficult to manage.

$4 \mathbf{j}$ requires students to have extensive initial knowledge to be successful.

$\mathbf{4 k}$ is not effective in underperforming students

$41 \mathrm{I}$ would need access to any adequate training program involving IBST.

$4 \mathrm{~m}$ I wouldn't have sufficient resources such as computers, laboratory, etc.

4n the number of students per class is usually too high for IBST practice to be effective.

\begin{tabular}{|c|c|c|c|}
\hline$\Gamma \mathrm{D}$ & D & $\mathbf{A}$ & TA \\
\hline 占 & 自 & 䄅 & - \\
\hline 然 & م & 曾 & \\
\hline$\frac{\text { of }}{\text { of }}$ & $\frac{n_{0}}{n^{\prime}}$ & 紫 & \\
\hline م. & 每 & 曾 & \\
\hline 紫 & م & 曾 & \\
\hline 然 & م & 曾 & \\
\hline م & 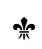 & 䗆 & \\
\hline 然 & م & 嘼 & \\
\hline 栔 & م. & 曾 & \\
\hline م. & $\frac{k}{6}$ & Pr & \\
\hline 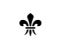 & $\frac{n_{0}}{n^{\prime}}$ & 曾 & \\
\hline 栔 & م & م. & \\
\hline 車 & 桌 & 备 & \\
\hline 桌 & 莮 & 䗆 & \\
\hline
\end{tabular}
4o. In addition to those already mentioned, do you any think there is other difficulty when applying inquiry? Justify your answer.

TD: totally disagree; D: disagree; A: agree; TA: totally agree 


\section{APPENDIX 2}

Statistical Results of the PSSTs Perceptions

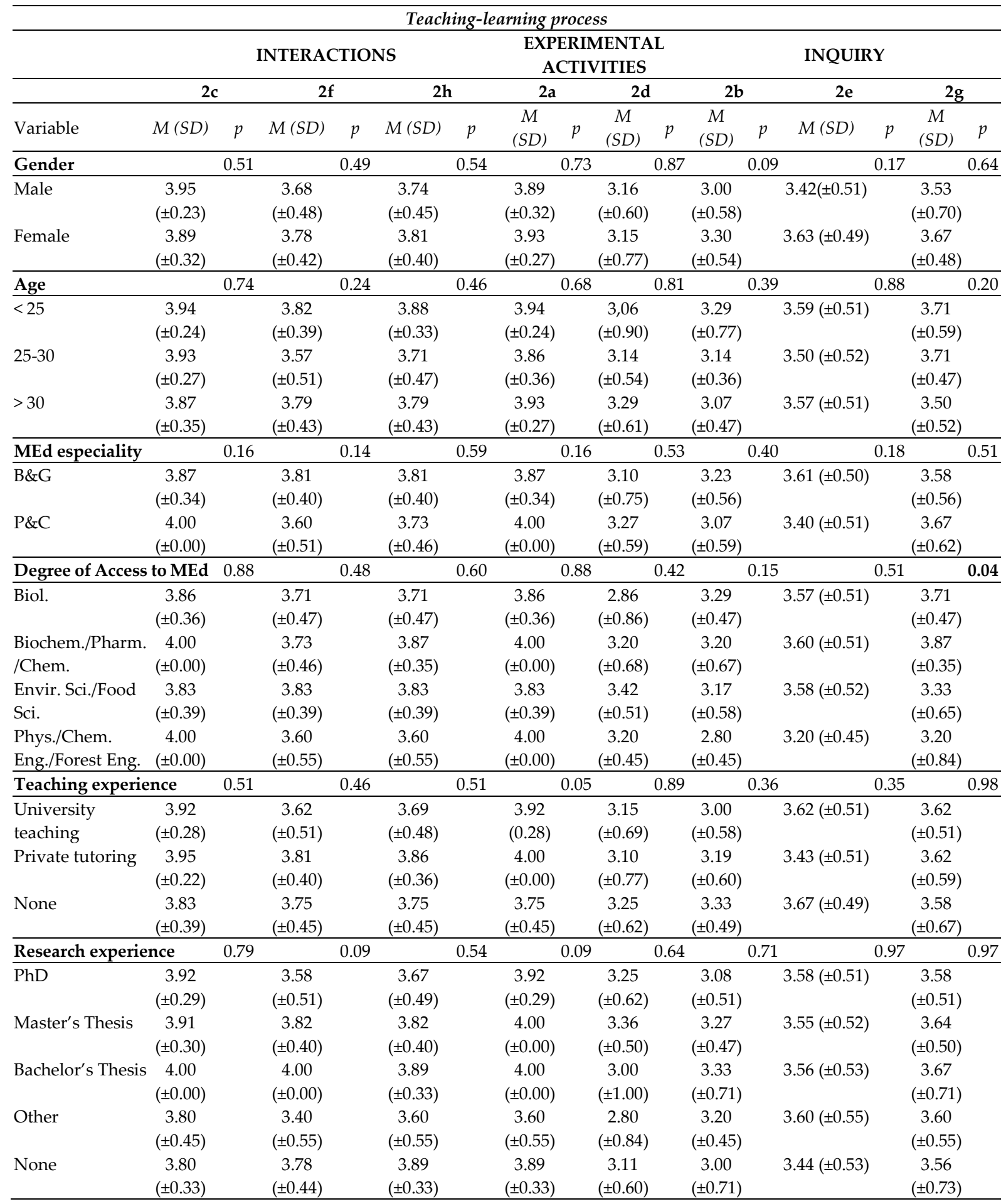

Values in bold represent statistically different perceptions $(\mathrm{p}<0.05)$ 


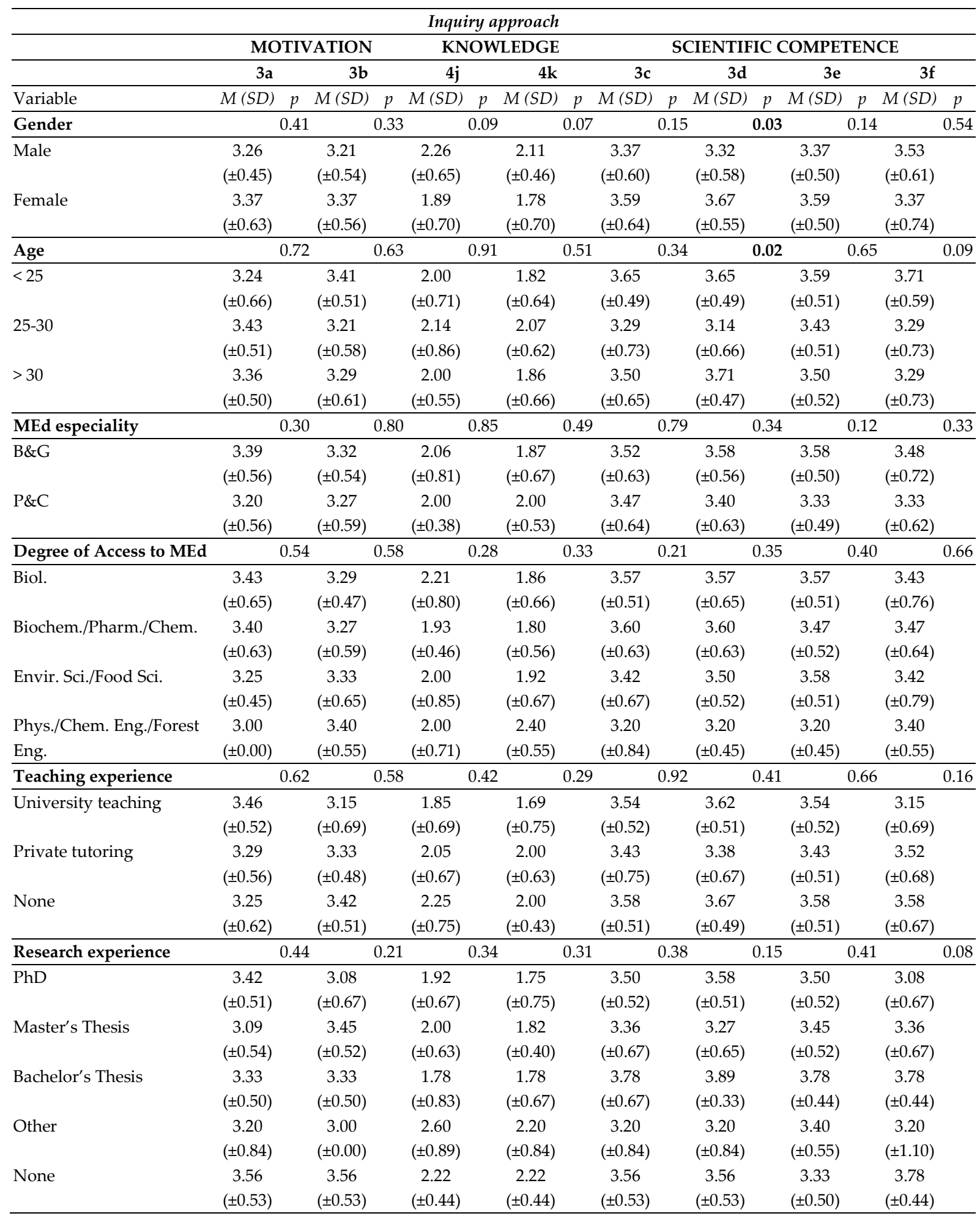

Values in bold represent statistically different perceptions $(\mathrm{p}<0.05)$ 


\begin{tabular}{|c|c|c|c|c|c|c|c|c|c|}
\hline \multicolumn{10}{|c|}{ Difficulties associated with resources and classroom management } \\
\hline & \multicolumn{4}{|c|}{ RESOURCES } & \multicolumn{5}{|c|}{ CLASSROOM MANAGEMENT } \\
\hline & $4 c$ & 4f & 41 & $4 \mathrm{~m}$ & $4 \mathrm{~b}$ & $4 e$ & $4 \mathrm{~h}$ & $4 \mathbf{i}$ & \\
\hline Variable & $M(S D)$ & $p \quad M(S D)$ & $p \quad M(S D)$ & $p \quad M(S D)$ & $p \quad M(S D)$ & $p \quad M(S D)$ & $p \quad M(S D)$ & $p \quad M(S D)$ & $p$ \\
\hline Gender & & 0.95 & 0.31 & 0.70 & 0.30 & 0.96 & 1.00 & 0.39 & 0.90 \\
\hline Male & $\begin{array}{c}2.63 \\
( \pm 0.68)\end{array}$ & $\begin{array}{c}2.37 \\
( \pm 0.68)\end{array}$ & $\begin{array}{c}2.26 \\
( \pm 0.56)\end{array}$ & $\begin{array}{c}2.79 \\
( \pm 0.79)\end{array}$ & $\begin{array}{c}2.42 \\
( \pm 0.61)\end{array}$ & $\begin{array}{c}2.53 \\
( \pm 0.61)\end{array}$ & $\begin{array}{c}2.95 \\
( \pm 0.71)\end{array}$ & $\begin{array}{c}2.79 \\
( \pm 0.71)\end{array}$ & \\
\hline Female & $\begin{array}{c}2.67 \\
( \pm 0.68) \\
\end{array}$ & $\begin{array}{c}2.59 \\
( \pm 0.68) \\
\end{array}$ & $\begin{array}{c}2.37 \\
( \pm 0.74) \\
\end{array}$ & $\begin{array}{c}2.56 \\
( \pm 0.80) \\
\end{array}$ & $\begin{array}{c}2.44 \\
( \pm 0.64)\end{array}$ & $\begin{array}{c}2.56 \\
( \pm 0.80)\end{array}$ & $\begin{array}{c}2.74 \\
( \pm 0.71)\end{array}$ & $\begin{array}{c}2.74 \\
( \pm 0.76)\end{array}$ & \\
\hline Age & & 0.87 & 0.06 & 0.08 & 0.61 & 0.96 & 0.43 & 0.33 & 0.12 \\
\hline$<25$ & $\begin{array}{c}2.65 \\
( \pm 0.79)\end{array}$ & $\begin{array}{c}2.29 \\
( \pm 0.77)\end{array}$ & $\begin{array}{c}2.12 \\
( \pm 0.60)\end{array}$ & $\begin{array}{c}2.65 \\
( \pm 0.93)\end{array}$ & $\begin{array}{c}2.35 \\
( \pm 0.62)\end{array}$ & $\begin{array}{c}2.59 \\
( \pm 0.62)\end{array}$ & $\begin{array}{c}2.94 \\
( \pm 0.66)\end{array}$ & $\begin{array}{c}3.00 \\
( \pm 0.79)\end{array}$ & \\
\hline $25-30$ & $\begin{array}{c}2.57 \\
( \pm 0.51)\end{array}$ & $\begin{array}{c}2.43 \\
( \pm 0.64)\end{array}$ & $\begin{array}{c}2.21 \\
( \pm 0.58)\end{array}$ & $\begin{array}{c}2.50 \\
( \pm 0.76)\end{array}$ & $\begin{array}{c}2.36 \\
( \pm 0.65)\end{array}$ & $\begin{array}{c}2.29 \\
( \pm 0.83)\end{array}$ & $\begin{array}{c}2.57 \\
( \pm 0.76)\end{array}$ & $\begin{array}{c}2.43 \\
( \pm 0.76)\end{array}$ & \\
\hline$>30$ & $\begin{array}{c}2.71 \\
( \pm 0.73)\end{array}$ & $\begin{array}{c}2.86 \\
( \pm 0.36)\end{array}$ & $\begin{array}{c}2.64 \\
( \pm 0.74)\end{array}$ & $\begin{array}{c}2.79 \\
( \pm 0.70)\end{array}$ & $\begin{array}{c}2.43 \\
( \pm 0.65)\end{array}$ & $\begin{array}{c}2.79 \\
( \pm 0.70)\end{array}$ & $\begin{array}{c}2.93 \\
( \pm 0.73)\end{array}$ & $\begin{array}{c}2.79 \\
( \pm 0.58)\end{array}$ & \\
\hline MEd especiality & & 0.06 & 0.50 & 0.46 & 0.65 & 0.37 & 0.49 & 0.44 & 0.54 \\
\hline$B \& G$ & $\begin{array}{c}2.77 \\
( \pm 0.72)\end{array}$ & $\begin{array}{c}2.45 \\
( \pm 0.62)\end{array}$ & $\begin{array}{c}2.35 \\
( \pm 0.71)\end{array}$ & $\begin{array}{c}2.61 \\
( \pm 0.88)\end{array}$ & $\begin{array}{c}2.42 \\
( \pm 0.63)\end{array}$ & $\begin{array}{c}2.48 \\
( \pm 0.77)\end{array}$ & $\begin{array}{c}2.77 \\
( \pm 0.81)\end{array}$ & $\begin{array}{c}2.81 \\
( \pm 0.79)\end{array}$ & \\
\hline $\mathrm{P} \& \mathrm{C}$ & $\begin{array}{c}2.42 \\
( \pm 0.51) \\
\end{array}$ & $\begin{array}{c}2.60 \\
( \pm 0.74) \\
\end{array}$ & $\begin{array}{c}2.27 \\
( \pm 0.59) \\
\end{array}$ & $\begin{array}{c}2.73 \\
( \pm 0.59) \\
\end{array}$ & $\begin{array}{c}2.27 \\
( \pm 0.62) \\
\end{array}$ & $\begin{array}{c}2.67 \\
( \pm 0.62) \\
\end{array}$ & $\begin{array}{c}2.93 \\
( \pm 0.46) \\
\end{array}$ & $\begin{array}{c}2.67 \\
( \pm 0.62) \\
\end{array}$ & \\
\hline Degree of Access to MEd & & 0.22 & 0.38 & 0.34 & 0.06 & 0.48 & 0.47 & 0.34 & 0.37 \\
\hline Biol. & $2.79( \pm 0.70)$ & $\begin{array}{c}2.29 \\
( \pm 0.61)\end{array}$ & $\begin{array}{c}2.36 \\
( \pm 0.50)\end{array}$ & $\begin{array}{c}2.57 \\
( \pm 0.76)\end{array}$ & $\begin{array}{c}2.48 \\
( \pm 0.76)\end{array}$ & $\begin{array}{c}2.71 \\
( \pm 0.83)\end{array}$ & $\begin{array}{c}2.79 \\
( \pm 0.80)\end{array}$ & $\begin{array}{c}2.86 \\
( \pm 0.86)\end{array}$ & \\
\hline Biochem./Pharm./Chem. & $\begin{array}{c}2.40 \\
( \pm 0.63)\end{array}$ & $\begin{array}{c}2.73 \\
( \pm 0.59)\end{array}$ & $\begin{array}{c}2.27 \\
( \pm 0.70)\end{array}$ & $\begin{array}{c}2.73 \\
( \pm 0.80)\end{array}$ & $\begin{array}{c}2.17 \\
( \pm 0.41)\end{array}$ & $\begin{array}{c}2.67 \\
( \pm 0.62)\end{array}$ & $\begin{array}{c}3.07 \\
( \pm 0.59)\end{array}$ & $\begin{array}{c}2.60 \\
( \pm 0.63)\end{array}$ & \\
\hline Envir. Sci./Food Sci. & $\begin{array}{c}2.83 \\
( \pm 0.72)\end{array}$ & $\begin{array}{c}2.58 \\
( \pm 0.67)\end{array}$ & $\begin{array}{c}2.33 \\
( \pm 0.89)\end{array}$ & $\begin{array}{c}2.50 \\
( \pm 0.90)\end{array}$ & $\begin{array}{c}2.37 \\
( \pm 0.51)\end{array}$ & $\begin{array}{c}2.33 \\
( \pm 0.78)\end{array}$ & $\begin{array}{c}2.67 \\
( \pm 0.78)\end{array}$ & $\begin{array}{c}2.75 \\
( \pm 0.75)\end{array}$ & \\
\hline $\begin{array}{l}\text { Phys./Chem. Eng./Forest } \\
\text { Eng. }\end{array}$ & $\begin{array}{c}2.60 \\
( \pm 0.55)\end{array}$ & $\begin{array}{c}2.20 \\
( \pm 0.84)\end{array}$ & $\begin{array}{c}2.40 \\
( \pm 0.55) \\
\end{array}$ & $\begin{array}{c}3.00 \\
( \pm 0.71)\end{array}$ & $\begin{array}{c}2.70 \\
( \pm 0.84)\end{array}$ & $\begin{array}{c}2.20 \\
( \pm 0.45)\end{array}$ & $\begin{array}{c}2.60 \\
( \pm 0.55)\end{array}$ & $\begin{array}{c}3.00 \\
( \pm 0.71)\end{array}$ & \\
\hline Teaching experience & & 0.03 & 0.92 & 0.95 & 0.11 & 0.23 & 0.82 & 0.38 & 0.31 \\
\hline University teaching & $\begin{array}{c}2.23 \\
( \pm 0.60)\end{array}$ & $\begin{array}{c}2.46 \\
( \pm 0.66)\end{array}$ & $\begin{array}{c}2.31 \\
( \pm 0.75)\end{array}$ & $\begin{array}{c}2.31 \\
( \pm 0.63)\end{array}$ & $\begin{array}{c}2.18 \\
( \pm 0.60)\end{array}$ & $\begin{array}{c}2.46 \\
( \pm 0.78)\end{array}$ & $\begin{array}{c}2.85 \\
( \pm 0.69)\end{array}$ & $\begin{array}{c}2.54 \\
( \pm 0.52)\end{array}$ & \\
\hline Private tutoring & $\begin{array}{c}2.86 \\
( \pm 0.73)\end{array}$ & $\begin{array}{c}2.48 \\
( \pm 0.75)\end{array}$ & $\begin{array}{c}2.33 \\
( \pm 0.66)\end{array}$ & $\begin{array}{c}2.86 \\
( \pm 0.73)\end{array}$ & $\begin{array}{c}2.45 \\
( \pm 0.68)\end{array}$ & $\begin{array}{c}2.62 \\
( \pm 0.74)\end{array}$ & $\begin{array}{c}2.95 \\
( \pm 0.59)\end{array}$ & $\begin{array}{c}2.95 \\
( \pm 0.80)\end{array}$ & \\
\hline None & $\begin{array}{r}2.75 \\
( \pm 0.45) \\
\end{array}$ & $\begin{array}{r}2.58 \\
( \pm 0.51) \\
\end{array}$ & $\begin{array}{r}2.33 \\
( \pm 0.65) \\
\end{array}$ & $\begin{array}{c}2.67 \\
( \pm 0.98) \\
\end{array}$ & $\begin{array}{r}2.45 \\
( \pm 0.52) \\
\end{array}$ & $\begin{array}{r}2.50 \\
( \pm 0.67) \\
\end{array}$ & $\begin{array}{r}2.58 \\
( \pm 0.90) \\
\end{array}$ & $\begin{array}{c}2.67 \\
( \pm 0.78) \\
\end{array}$ & \\
\hline Research experience & & 0.11 & 0.91 & 0.80 & 0.22 & 0.69 & 0.28 & 0.96 & 0.13 \\
\hline $\mathrm{PhD}$ & $\begin{array}{c}2.25 \\
( \pm 0.45)\end{array}$ & $\begin{array}{c}2.58 \\
( \pm 0.67)\end{array}$ & $\begin{array}{c}2.33 \\
( \pm 0.78)\end{array}$ & $\begin{array}{c}2.25 \\
( \pm 0.62)\end{array}$ & $\begin{array}{c}2.27 \\
( \pm 0.65)\end{array}$ & $\begin{array}{c}2.42 \\
( \pm 0.90)\end{array}$ & $\begin{array}{c}2.67 \\
( \pm 0.78)\end{array}$ & $\begin{array}{c}2.33 \\
( \pm 0.65)\end{array}$ & \\
\hline Master's Thesis & $\begin{array}{c}2.73 \\
( \pm 0.65)\end{array}$ & $\begin{array}{c}2.55 \\
( \pm 0.69)\end{array}$ & $\begin{array}{c}2.18 \\
( \pm 0.60)\end{array}$ & $\begin{array}{c}2.82 \\
( \pm 0.87)\end{array}$ & $\begin{array}{c}2.40 \\
( \pm 0.52)\end{array}$ & $\begin{array}{c}2.45 \\
( \pm 0.69)\end{array}$ & $\begin{array}{c}2.82 \\
( \pm 0.40)\end{array}$ & $\begin{array}{c}2.82 \\
( \pm 0.60)\end{array}$ & \\
\hline Bachelor's Thesis & $\begin{array}{c}2.67 \\
( \pm 0.71)\end{array}$ & $\begin{array}{c}2.44 \\
( \pm 0.73)\end{array}$ & $\begin{array}{c}2.33 \\
( \pm 0.87)\end{array}$ & $\begin{array}{c}2.56 \\
( \pm 0.88)\end{array}$ & $\begin{array}{c}2.29 \\
( \pm 0.50)\end{array}$ & $\begin{array}{c}2.44 \\
( \pm 0.53)\end{array}$ & $\begin{array}{c}2.89 \\
( \pm 0.78)\end{array}$ & $\begin{array}{c}3.11 \\
( \pm 0.60)\end{array}$ & \\
\hline Other & $\begin{array}{c}3.00 \\
( \pm 0.71)\end{array}$ & $\begin{array}{c}2.60 \\
( \pm 0.55)\end{array}$ & $\begin{array}{c}2.60 \\
( \pm 0.55)\end{array}$ & $\begin{array}{c}3.00 \\
( \pm 0.71)\end{array}$ & $\begin{array}{c}2.70 \\
( \pm 0.84)\end{array}$ & $\begin{array}{c}3.20 \\
( \pm 0.45)\end{array}$ & $\begin{array}{c}3.00 \\
( \pm 1.00\end{array}$ & $\begin{array}{c}2.60 \\
( \pm 0.89)\end{array}$ & \\
\hline None & $\begin{array}{c}2.89 \\
( \pm 0.78)\end{array}$ & $\begin{array}{c}2.33 \\
( \pm 0.71)\end{array}$ & $\begin{array}{c}2.33 \\
( \pm 0.50)\end{array}$ & $\begin{array}{c}2.89 \\
( \pm 0.78)\end{array}$ & $\begin{array}{c}2.36 \\
( \pm 0.73)\end{array}$ & $\begin{array}{c}2.56 \\
( \pm 0.73)\end{array}$ & $\begin{array}{c}2.89 \\
( \pm 0.78)\end{array}$ & $\begin{array}{c}3.00 \\
( \pm 0.87)\end{array}$ & \\
\hline
\end{tabular}

Values in bold represent statically different perceptions $(\mathrm{p}<0.05)$ 


\begin{tabular}{|c|c|c|c|c|c|c|c|c|}
\hline \multicolumn{9}{|c|}{ Difficulties associated with system restrictions } \\
\hline & \multicolumn{8}{|c|}{ SYSTEM RESTRICTIONS } \\
\hline & $4 a$ & & $4 \mathrm{~d}$ & & $4 \mathrm{~g}$ & & $4 n$ & \\
\hline Variable & $M(S D)$ & $p$ & $M(S D)$ & $p$ & $M(S D)$ & $p$ & $M(S D)$ & $p$ \\
\hline Gender & & 0.70 & & 0.20 & & 0.93 & & 0.37 \\
\hline Male & $2.68( \pm 0.67)$ & & $3.11( \pm 0.57)$ & & $2.74( \pm 0.45)$ & & $2.84( \pm 0.76)$ & \\
\hline Female & $2.56( \pm 0.85)$ & & $2.78( \pm 0.89)$ & & $2.74( \pm 0.59)$ & & $2.67( \pm 0.78)$ & \\
\hline Age & & 0.23 & & 0.58 & & 0.44 & & 0.64 \\
\hline$<25$ & $2.35( \pm 0.79)$ & & $2.76( \pm 0.83)$ & & $2.76( \pm 0.56)$ & & $2.82( \pm 0.81)$ & \\
\hline $25-30$ & $2.79( \pm 0.70)$ & & $2.93( \pm 0.83)$ & & $2.86( \pm 0.54)$ & & $2.57( \pm 0.76)$ & \\
\hline$>30$ & $2.79( \pm 0.80)$ & & $3.00( \pm 0.68)$ & & $2.64( \pm 0.50)$ & & $2.79( \pm 0.80)$ & \\
\hline MEd especiality & & 0.90 & & 0.09 & & 0.97 & & 0.22 \\
\hline$\overline{B \& G}$ & $2.58( \pm 0.81)$ & & $2.77( \pm 0.80)$ & & $2.74( \pm 0.58)$ & & $2.65( \pm 0.84)$ & \\
\hline P\&C & $2.67( \pm 0.72)$ & & $3.20( \pm 0.68)$ & & $2.73( \pm 0.46)$ & & $2.93( \pm 0.59)$ & \\
\hline Degree of Access to MEd & & 0.36 & & 0.59 & & 0.67 & & 0.20 \\
\hline Biol. & $2.50( \pm 0.76)$ & & $2.86( \pm 0.77)$ & & $2.64( \pm 0.50)$ & & $2.79( \pm 0.80)$ & \\
\hline Biochem./Pharm./Chem. & $2.67( \pm 0.82)$ & & $3.00( \pm 0.76)$ & & $2.67( \pm 0.49)$ & & $2.73( \pm 0.70)$ & \\
\hline Envir. Sci./Food Sci. & $2.83( \pm 0.83)$ & & $2.75( \pm 0.97)$ & & $2.92( \pm 0.67)$ & & $2.58( \pm 0.90)$ & \\
\hline Phys./Chem. Eng./Forest Eng. & $2.20( \pm 0.45)$ & & $3.20( \pm 0.45)$ & & $2.80( \pm 0.45)$ & & $3.00( \pm 0.71)$ & \\
\hline Teaching experience & & 0.38 & & 0.23 & & 0.01 & & 0.02 \\
\hline University teaching & $2.38( \pm 0.65)$ & & $2.69( \pm 0.63)$ & & $2.54( \pm 0.52)$ & & $2.31( \pm 0.75)$ & \\
\hline Private tutoring & $2.62( \pm 0.86)$ & & $3.10( \pm 0.83)$ & & $3.00( \pm 0.32)$ & & $3.05( \pm 0.59)$ & \\
\hline None & $2.83( \pm 0.72)$ & & $2.83( \pm 0.83)$ & & $2.50( \pm 0.67)$ & & $2.67( \pm 0.89)$ & \\
\hline Research experience & & 0.96 & & 0.09 & & 0.78 & & 0.07 \\
\hline$\overline{\mathrm{PhD}}$ & $2.50( \pm 0.80)$ & & $2.58( \pm 0.79)$ & & $2.58( \pm 0.67)$ & & $2.33( \pm 0.78)$ & \\
\hline Master's Thesis & $2.64( \pm 0.50)$ & & $2.82( \pm 0.75)$ & & $2.82( \pm 0.60)$ & & $2.91( \pm 0.54)$ & \\
\hline Bachelor's Thesis & $2.56( \pm 0.88)$ & & $2.78( \pm 0.67)$ & & $2.78( \pm 0.44)$ & & $2.56( \pm 0.88)$ & \\
\hline Other & $2.80( \pm 1.30)$ & & $3.60( \pm 0.89)$ & & $2.80( \pm 0.45)$ & & $3.40( \pm 0.55)$ & \\
\hline None & $2.67( \pm 0.71)$ & & $3.22( \pm 0.67)$ & & $2.78( \pm 0.44)$ & & $2.89( \pm 0.78)$ & \\
\hline
\end{tabular}

Values in bold represent statistically different perceptions $(\mathrm{p}<0.05)$ 